\title{
Cysticercosis in Fallow Deer in England
}

\author{
Norma G. CHAPMAN \& Donald I. CHAPMAN
}

\begin{abstract}
Chapman N. G. \& Chapman D. I., 1987: Cysticercosis in fallow deer in England. Acta theriol., 32, 8: 105-113 [With 3 Tables \& 4 Figs.]

The bladderworm cyst Cysticercus tenuicollis Rudolphi, 1819 was found in 38 of 309 (12.3 per cent) of fallow deer (Dama dama Linnaeus, 1758) examined from three captive and three free-ranging populations in Southern England. The findings report a minimum incidence as only macroscopic examination was performed and livers were not sliced. Most infected deer had only one cysticercus and the maximum number in one deer was three: 91.3 per cent of the cysticerci were attached to the mesenteries or omentum. The difference in incidence between captive and free-living deer was not statistically significant. Deer older than one year had a higher incidence of infection than younger animals: the youngest infected was 8 months old.

[Larkmead, Barton Mills, Suffolk, IP28 6AA, England]
\end{abstract}

\section{INTRODUCTION}

The presence of the bladderworm cyst Cysticercus tenuicollis in deer in Britain is said to indicate that the hosts have grazed ground used by dogs (Canis familiaris Linnaeus, 1758) or foxes (Vulpes vulpes Linnaeus, 1758), the carnivores most likely to be the definitive host for the adult tapeworm, Taenia hydatigena Pallas, 1766. The bladderworm is considered to be of trival importance as it occurs on the serous membranes of the abdominal cavity and can cause harm only if large numbers migrate through the liver (Dunn, 1967). It is the only larval cestode which has been recorded in wild deer in Britain (Dunn, 1969).

C. tenuicollis is cosmopolitan in its choice of host which is usually a ruminant or swine. The number and location of the cysticerci appear to vary according to the host species. The incidence and location of these larvae in British fallow deer (Dama dama Linnaeus, 1758) are virtually unknown. It was not recorded for fallow in the review of helminths of British deer (Dunn, 1967). The first report appears to be in 1970 (Batty \& Chapman, 1970) when one of the 26 fallow examined had a single cysticercus. As part of a study of fallow deer we have investigated their helminths. This paper reports results on the incidence of cysticerci in captive and free-ranging populations from differing habitats. 
106

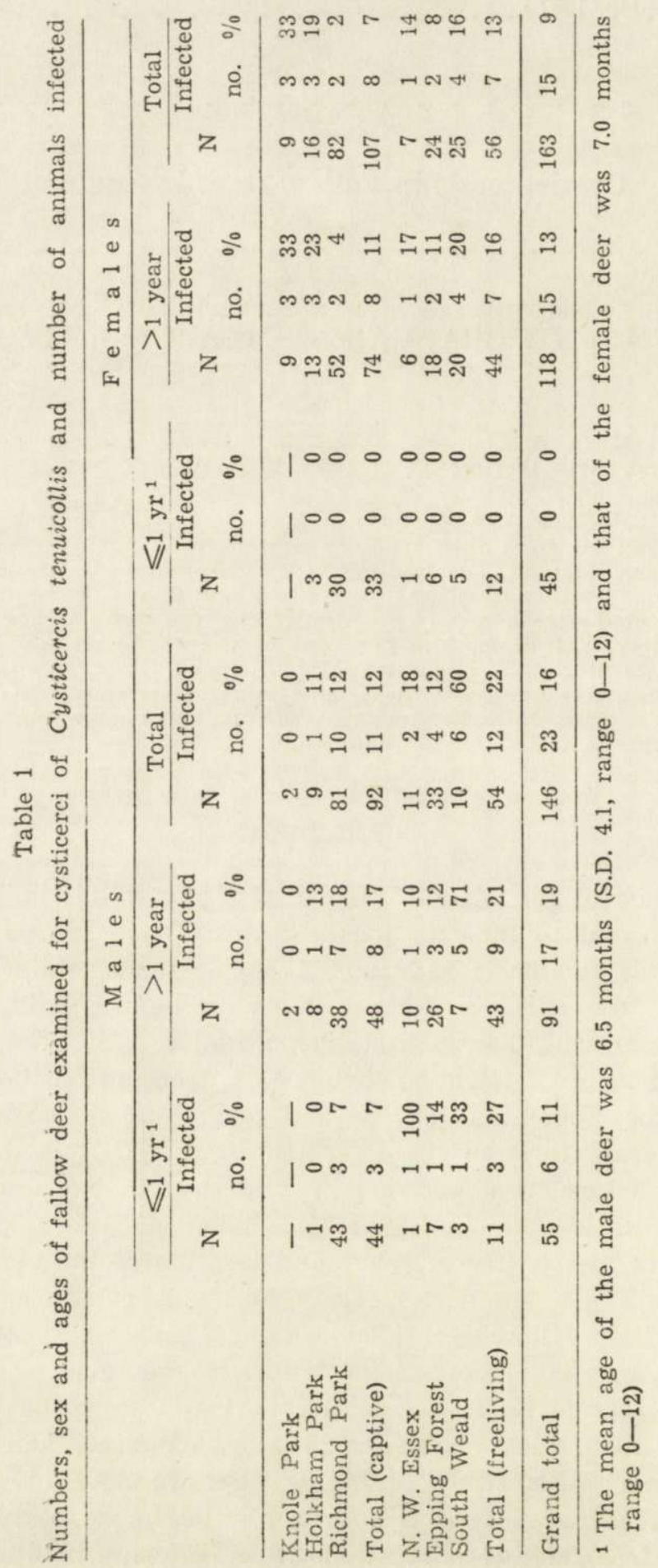




\section{MATERIAL AND METHODS}

\subsection{Animals}

A total of 309 deer, from three parks and three other areas, were examined. Carcasses were obtained throughout the year: the monthly sample size ranged from 11 to 65 (Fig. 1). The sample from each locality was divided into four groups according to sex and age (less or more than one year old). The ages were estimated from the eruption and wear of the molariform teeth in comparison with specimens from known-age deer from two (one park, one wild) of the localities (Chapman \& Chapman, 1975). Details of the animals are given in Table 1. A few deer had died naturally but the majority were shot or killed

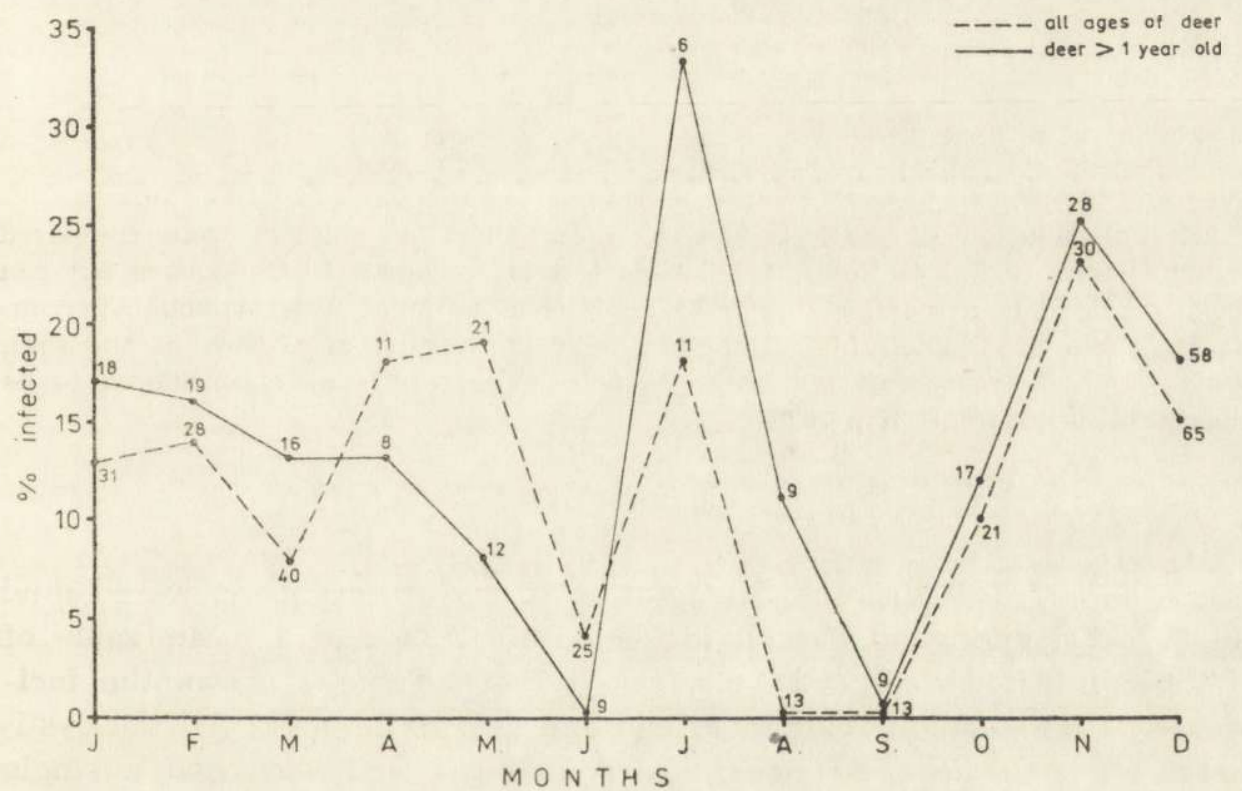

Fig. 1. Monthly sample size and incidence of cystercerci.

in accidents. The abdominal organs and lungs were examined macroscopically, usually without dissection, for the presence of mature cysticerci. The abdominal fluid was not examined for larvae and the livers were not sliced.

\subsection{Study Areas}

Data pertaining to the parks at the time of the survey are given in Table 2. Foxes and dogs were present in each of the parks but only at Richmond Park could they possibly gain access to the disposed viscera of culled deer.

The free-ranging deer came from three areas of Essex: Epping Forest and its environs, South Weald near Brentwood and, with two exceptions from mid-Essex, from North-west Essex. These areas all included deciduous woodland with arable land and pasture (Chapman, 1977). Foxes and dogs occurred in all the areas. 
Table 2

Data pertaining to the parks from which fallow deer were examined.

\begin{tabular}{|c|c|c|c|}
\hline Park & Holkham & Knole & Richmond \\
\hline Location & $\begin{array}{l}\text { Wells-next-the- } \\
\text { Sea, Norfolk }\end{array}$ & $\begin{array}{l}\text { Sevenoaks, } \\
\text { Kent }\end{array}$ & $\begin{array}{l}\text { Richmond, } \\
\text { Surrey }\end{array}$ \\
\hline $\begin{array}{l}\text { Area to which } \\
\text { deer had access }\end{array}$ & $\begin{array}{l}130 \text { ha pasture \& } \\
\text { deciduous } \\
\text { woodland }\end{array}$ & 340 ha pasture & $\begin{array}{l}950 \text { ha pasture } \\
\& \text { deciduous } \\
\text { woodland }\end{array}$ \\
\hline No. fallow deer & c. 850 & c. 500 & $300-400$ \\
\hline $\begin{array}{l}\text { Other grazing } \\
\text { stock }\end{array}$ & $\begin{array}{l}\text { all year: - } \\
\text { spring/summer: } \\
\text { c. } 750 \text { sheep } \\
\text { autumn: c. } 100 \\
\text { cattle }\end{array}$ & c. 220 sika deer & $\begin{array}{l}250-350 \text { red deer } \\
\text { Apr.-Sept.: } 300- \\
400 \text { sheep }\end{array}$ \\
\hline
\end{tabular}

\subsection{Statistical Analysis}

The distribution of cysticerci between categories of animals were compared using G-tests (Sokal \& Rohlf, 1969). This test is analagous to Chi-square but can be partitioned in a manner similar to analysis of variance tests. Although percentage figures are quoted in conjunction with the results of G-tests in the text, tests were always carried out on frequencies. The results were considered to be significantly different if $p<0.05$.

\section{RESULTS}

In the 309 deer examined, a total of 46 mature cysticerci were found in 38 deer, giving an overall incidence of $12.3 \%$ and a mean value of 1.2 per infected deer (S.D. 0.5, range $1-3$ ). Table 1 shows the incidence of infection in relation to age and sex of the deer. All the cysticerci were Cysticercus tenuicollis. Thirty-two deer each had a single cysticercus, four deer each had two and two deer each had three cysts. The majority $(91.3 \%)$ or the cysticerci were attached to the omentum or the mesenteries, with the remainder either on the liver $(4.3 \%)$ or attached to the muscles of the abdomen (4.3\%). The cysticerci were usually about $20 \mathrm{~mm}$ in diameter but the largest measured $40 \mathrm{~mm}$.

Thirty-two of the 209 deer older than one year $(15.3 \%)$ and six of the 100 immature deer were infected, the difference being statistically significant $(G=6.07, p<0.02)$. The youngest animal found to be infected was an eight-month old fawn from Richmond Park. These agerelated differences in the incidence of infection were significant in females $(<1$ year, $0 \%,>1$ year, $11 \%$ : $\mathrm{G}=6.71, p<0.01)$ but not in males (Fig. 2).

In general, male deer were more frequently infected than females 
$(\mathrm{G}=3.07,0.1>p>0.05$ and this difference was significant among fawns $(\mathrm{G}=4.14, p<0.05)$, (Fig. 2). This appeared to be a localised effect since the only significant differences between the sexes were from Richmond Park $(G=4.72, p<0.05)$ and South Weald $(G=4.55, p<0.05)$.

Free-ranging deer tended to have a greater incidence of infection with cysticerci than did the captive deer $(G=3.78,0.1>p>0.05)$, (Fig. 3). The frequency of infection tended to vary among the three wild pop-

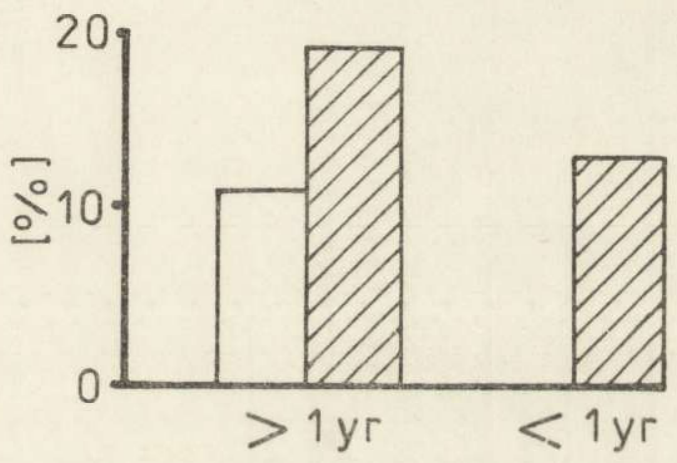

Fig. 2. Percentage incidence of infestion of $C$. tenuicollis relation to age and sex of host. Females - open bars, males - hatched bars.

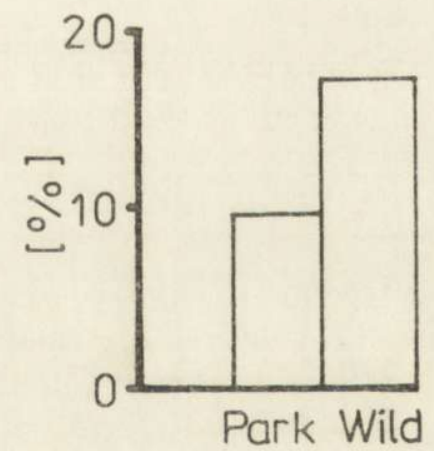

Fig. 3. Percentage incidence of infection of $C$. tenuicollis in park and free-living fallow deer.

ulations $\left(\mathrm{G}_{2}=4.55,0.1>p>0.05\right)$ from $11.8 \%$ in Epping Forest to $30 \%$ at South Weald. There also tended to be differences between park populations $\left(\mathrm{G}_{2}=4.80,0.1>p>0.05\right)$.

The incidence of infection varied significantly between seasons in females $\left(G_{2}=6.97, p<0.05\right)$ and tended to vary in males $\left(G_{2}=5.10\right.$, $0.1>p>0.05)$. However the timing of peak infection differed between 
the sexes (Fig. 4). Females were most infected in winter (October March, 16.5\%) and least infected in April - June (0\%). In contrast, males were most infected in April - June (26.9\%) and least infected in June - September (4.3\%). Only in April - June were the differences in frequency of infection significantly different between the sexes $(G=8.10, p<0.01)$.

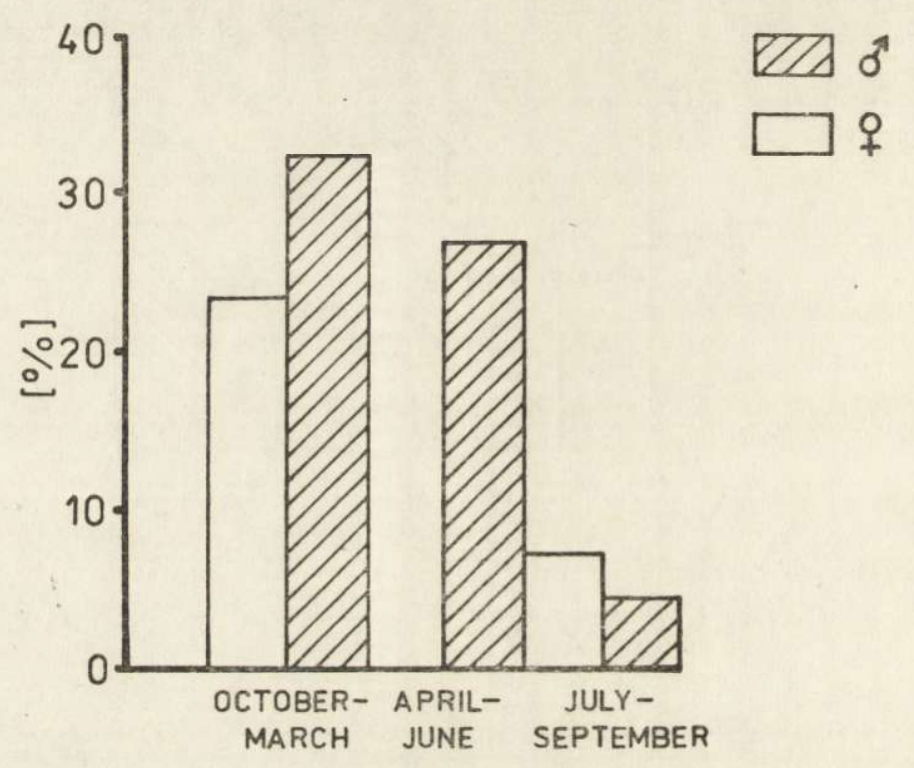

Fig. 4. Seasonal incidence of C. tenuicollis found in fallow deer.

\section{DISCUSSION}

The incidence of infection found in the present study is compared with other published results in Table 3. Information on the degree of infection in other species of deer in Britain seems to be lacking. No cysticerci have been found in 120 muntjac (Muntiacus reevesi Ogilby, 1839) from eight counties nor in the gastro-intestinal tracts of 50 roe deer (Capreolus capreolus Linnaeus, 1758) from Suffolk (personal observations). In Hungary Murai and Sugár $(1976,1979)$ reported incidences of $24 \%$ and $41 \%$ in red deer (Cervus elaphus Linnaeus, 1758) and $61 \%$ and $49 \%$ in roe deer.

In general, the incidence of infection by $C$. tenuicollis in fallow deer appears lower than that recorded for some species of deer in North America where, in some areas, over $80 \%$ were infected (Leiby \& Dyer, 1971).

The majority of the cysticerci were located on the omentum or mes- 
enteries, which were also the most usual sites recorded in roe deer in one locality in Dorset (McDiarmid, 1968). The Hungarian studies on the three species of deer, wild boar (Sus scrofa Linnaeus, 1758) and mouflon (Ovis musimon Pallas, 1811) reported that most cysticerci were on the omentum, with some on the liver, in the lungs or the pelvic region (Murai \& Sugár, 1979). Similarly, in mule deer (Odocoileus hemionus Rafinesque, 1817) the larvae were most frequent on the omentum (Cowan, 1946) but in Alaskan reindeer (Rangifer tarandus Linnaeus, 1758) they occurred primarily in the liver (Neilund, 1972).

The maximum number of cysticerci per fallow deer was 3 whereas in one mule deer 23 were found, although the mean was only 3.6 (Cowan, 1946). Reindeer seldom had more than 5-10 (Neilund, 1972). In Murai and Sugár's survey (1979) a range of 1-25 cysticerci was recorded in five intermediate hosts but the figures for fallow deer were not reported separately.

Table 3

Incidence of infection by Cysticercus tenuicollis in fallow deer.

\begin{tabular}{|c|c|c|c|c|}
\hline Country & & $\begin{array}{l}\text { No. deer } \\
\text { examined }\end{array}$ & $\%$ incidence & Reference \\
\hline \multirow[t]{2}{*}{ England } & 1) & 309 & 12.3 & Present study \\
\hline & 2) & 26 & 3.8 & Batty \& Chapman, 1970 \\
\hline Eire & & 16 & 12.5 & Sleeman, 1983 \\
\hline \multirow[t]{2}{*}{ Hungary } & 1) & 49 & 12.3 & Murai \& Sugár, 1976 \\
\hline & 2) & 35 & 20 & Murai \& Sugár, 1979 \\
\hline Poland & & 13 & 7.7 & Dróżdż, 1966 \\
\hline \multirow[t]{2}{*}{ Czechoslovakia } & 1) & 323 & 0.9 & Kotrlý, 1964 \\
\hline & 2) & 476 & 3.9 & Kotrlá \& Kotrlý, 1975 \\
\hline \multirow[t]{3}{*}{ New Zealand } & 1) & 67 & 9.0 & Sweatman \& Williams, 1962 \\
\hline & 2) & 30 & 0.0 & Sweatman \& Williams, 1962 \\
\hline & 3) & 6 & 67 & Sweatman \& Williams, 1962 \\
\hline
\end{tabular}

Older deer have had longer in which to ingest tapeworm eggs so the greater incidence of cysticerci in the older age category was expected. However, of the 53 deer over six years old, only $7 \%$ of the males and $9 \%$ of the females were infected.

The significantly greater incidence of infection among males at Richmond Park might be attributed to the adult males greater tendency to scavenge at litter bins (Chapman \& Chapman, 1975). These were sited at car parks where very many dogs began their exercise, probably depositing more faeces and a greater number of tapeworm eggs in the vicinity. However, this behaviour does not apply to fawns which showed the more significant difference between the sexes, and at South Weald four of the five infected males were under 19 months old and probably ranged over the same ground as the female deer. 
Variation in the incidence of infection among the various populations may reflect variation in the incidence of T. hydatigena in the carnivore hosts and this was unknown. A survey by Bereford-Jones (1961) or helminths in foxes included nine localities in Essex but Taenia was not identified to specific level. Cook and Clarkson (1971) did not find $T$. hydatigena in any of the 59 dogs examined from 33 farms in East Anglia, including north-west Essex.

It was not possible to determine the months in which the deer had become infected but seasonal variation in the incidence of infection is surprising since once a cysticercus has matured it will remain in its host for many years. Little is known of longevity of $C$. tenuicollis but a female fallow that died 11.5 years after being brought into captivity had an apparently viable cysticercus (personal observation). As no dogs or foxes had access to the paddock she presumably had become infected when in the wild.

Acknowledgements: Drs. Arlene Jones and L. F. Khalil of the Commonwealth Institute of Parasitology kindly identified the cysticerci and A. F. Batty made valued comments on an earlier draft of the paper. Dr. S. Albon's statistical analysis is very gratefully acknowledged. Thanks also are expressed to the authorities and gamekeepers of the three parks, to the late Col. V. S. Laurie of South Weald, Mr. P. Curtis, Messrs. A. Qvist and J. Besent, the former and present Superintendents of Epping Forest, and to members of the Essex Constabulary.

\section{REFERENCES}

1. Batty A. F. \& Chapman D. I., 1970: Gastro-intestinal parasites of wild fallow deer (Dama dama L.) J. Helminth., 44: 57-61.

2. Beresford-Jones W. P., 1961: Observations on the helminths of British Wild Red Foxes. Vet. Rec., 73: 882-883.

3. Chapman D. I., 1977: Deer of Essex. Essex Naturalist, 1: 1-150.

4. Chapman D. \& Chapman N., 1975: Fallow Deer: their history, distribution and biology. Terence Dalton Ltd.: 1-271. Lavenham.

5. Cook B. R. \& Clarkson M. J., 1971: Echinococcus granulosus and cestodes of the genus Taenia in farm dogs in the Lake District, northern Pennines and East Anglia. Ann. trop. Med. Parasit., 65: 71-79.

6. Cowan I. McT., 1946: Parasites, diseases, injuries, and anomalies of the Columbian black-tailed deer, Odocoileus hemionus columbianus (Richardson) in British Columbia. Can. J. Res., D, 24: 71-103.

7. Dróżdż J., 1966: Studies on helminths and helminthiases in Cervidae. II. The helminth fauna in Cervidae in Poland. Acta Parasit. Polonica, 14: 1-13.

8. Dunn A. M., 1967: Endoparasites of Deer. Deer, 1: 85-90.

9. Dunn A. M., 1969: The wild ruminant as reservoir host of helminth infection [In: "Diseases in Free-Living Wild Animals". McDiarmid, A. ed.] Symp. zool. Soc. Lond., 24: 221-248. Academic Press, London.

10. Kotrlý A., 1964: Ecology of parasites on game of the Family Cervidae and Bovidae. Prace vyzkumnych ústavú lesnických CSSR, 29: 5-47.

11. Kotrlá B. \& Kotrlý A., 1975: Development of the helminth fauna of the Dama 
dama in the Březka Game Preserve. Acta vet. Brno, 44: 235-244.

12. Leiby P. D. \& Dyer W. G., 1971: Cyclophyllidean tapeworm in wild carnivora. [In: "Parasitic Diseases of Wild Mammals". J. W. Davis \& R. C. Anderson, eds.] Iowa State Univ. Press: 174-234. Ames.

13. McDiarmid A., 1968: Some parasites and diseases of roe deer [In: "The Roe Deed of Cranborne Chase". R. Prior] Oxford University Press: 183-208. London.

14. Murai E. \& Sugár L., 1976: The tapeworms of mammals in Hungary. II. Species of Taeniidae from predatory animals, further cases of cysiucercosis and echinococcosis. Allatt. Közl., 63: 103-115.

15. Murai E. \& Sugár L., 1979: Taeniid species in Hungai, Cestoda, Taeniidae). I. Cysticercosis, Coenurosis and Hydatidosis of Wild Ungulates. Farasit. Hung., 12: $41-52$.

16. Neilund K. A., 1972: Caribou disease studies. Final Report, Alaska Dept. Fish and Game.

17. Sleeman D. P., 1983: Parasites of deer in Ireland. J. Life Sci., Roy. Dublin Soc., 4: 203-210.

18. Sokal R. R. \& Rohlf F. J., 1969: Biometry. Freeman: 1-776. San Francisco.

19. Sweatman G. K. \& Williams R. J., 1962: Wild animals in New Zealand as hosts of Echinococcus granulosus and other Taeniid tapeworms. Trans. R. Soc. N. Z., 2: $221-250$.

Received, August 22, 1985. Accepted, October 4, 1985.

Norma G. CHAPMAN i

D. I. CHAPMAN

WĄGRZYCA DANIELI W ANGLII

Streszczenie

Wągry Cysticercus tenuicollis Rudolphi, 1819 wykryto u $39(12.3 \%)$ spośród 309 danieli (Tabela 1). Badane zwierzęta pochodzily $z$ trzech zagrodowych $i$ trzech wolno-żyjących populacji tego gatunku z polưdniowej Anglii (Tabela 2). Niniejsza praca podaje tylko minimalne liczby zainfekowanych osobników, ponieważ przeprowadzono jedynie makroskopowe badania jamy brzusznej. U większości zainfekowanych danieli stwierdzono obecność 1 cysty (maksyalnie 3 cysty u jednego osobnika). W $91.3 \%$ przypadków pasożyt występowal w krezce i na sieci. Różnice między danielami z hodowli zagrodowej i z wolności nie były istotne statystycznie (Ryc. 3). Zwierzęta powyżej 1 roku byly zainfekowane częściej niż osobniki młode. Najmłodszym osobnikiem, u jakiego stwierdzono Cysticercus tenuicollis, było zwierzę 8-miesięczne. 